\title{
PREMENSTRUAL STRESS SYNDROME AS A DEFENSE IN CRIMINAL CASES
}

Premenstrual stress syndrome (PMS syndrome) is a disorder afflicting many women. ${ }^{1}$ The symptoms of PMS syndrome include excessive thirst and appetite, bloating, headaches, anxiety, depression, irritability, and general lethargy. ${ }^{2}$ Diagnosis depends on the timing of the symptoms rather than on their type, number, or severity; ${ }^{3}$ not all patients experience all possible symptoms. The syinptoms develop and increase in intensity from seven to fourteen days prior to the onset of menses and disappear rapidly thereafter. ${ }^{4}$ PMS syndrome can range in severity from mild to incapacitating, in both a physical and psychological sense. ${ }^{5}$

Recently, in England, female defendants in separate criminal actions successfully pleaded diminished responsibility or mitigating circumstances by establishing that they suffered from PMS syndroine. ${ }^{6}$ It has been reported that France also recognizes PMS syndrome as a form of legal imsamity. The use of PMS syndrome as the basis for a diminished capacity defense in England, and increased research and awareness of the syndrome in the medical commumity, has sparked debate in the United States legal community concerning the

1. Estimates of the precise percentage of women in the population who suffer from PMS syndrome vary. The best current research, however, indicates that 70-90\% of the female population experience premenstrual symptoms while 20-40\% experience some type of physical or mental incapacity. Reid \& Yen, Premenstrual Syndrome, 139 AM. J. OBSTET. AND GYNECOL. 85, 86 (1981). See also Pert, Medical, Psychiatric, and Legal Aspects of Premensirual Tension, 115 AM. J. PSYCHOLOGY 211, 211-12 (1958).

2. Reid \& Yen, supra note 1, at 86. PMS symptoms may also include craving for sweets, back pain, breast tenderness, and constipation. Id.

3. $I d$.

4. The period during which premenstrual symptoms are present and the menstrual period itself is often referred to as the paramenstruum. See d'Orban \& Dalton, Violent Crime and the Mensinual Cycle, 10 Psychological Med. 353, 354 (1980).

5. Reid \& Yen, Jupra note, 1 , at 86.

6. Tybor, Women on Trial: New Defense, 4 NAT'L L.J. 1, 16 (Feb. 15, 1982); Dalton, Cyclical Criminal Acts in Premenstrual Syndrome, LaNCET 1070, 1070 (Nov. 15, 1980) [hereinafter cited as Cyelical Criminal Acts].

7. Oleck, Legal Aspects of Premensirual Tension, 166 INT’L REC. OF MED. 492, 496 (1953). Oleck cites no authority for his statement that premenstrual tension falls within the category of temporary insanity in France. Nevertheless researchers and writers in this area have accepted and cited Oleck for the assertion that a tenporary insanity defense based on PMS syndrome exists in France. See, eg., d'Orban \& Dalton, supra note 4, at 353 (citing Oleck); Tybor, supra note 6; Hénig, Dispelling Menstrual Myths, N.Y. Times, Mar. 7, 1982, \& 6 (Magazine), at 79. 
admissibility of evidence to prove PMS syndrome. ${ }^{8}$

In an effort to resolve this debate, this note first discusses the context in which a defendant in a crimmal action might seek to use expert testimony to establish that she suffered from PMS syndrome. 9 Second, the note discusses the two evidentiary standards used by courts to evaluate a proffer of expert testimony on novel scientific evidence. ${ }^{10}$ Finally, the two standards are applied to evaluate the admissibility of expert testimony proffered to establish that the defendant suffers from PMS syndrome. ${ }^{11}$

\section{Defenses Based on PMS Syndrome}

A defendant might seek to prove that she suffered from PMS syndrome either to establish a complete insanity defense or to establish a defense of diminished capacity. ${ }^{12}$ No scientific evidence indicates that PMS syndrome alone can produce psychosis; ${ }^{13}$ thus, there is hittle hope that an insanity defense based on PMS syndrome would succeed. ${ }^{14}$

PMS syndrome may, however, provide a basis for a defense of diminished capacity. The diminished capacity defense, if recognized by a given jurisdiction, applies when a crime requires a specific state of mind; to prove diminished capacity, the defendant must establish that she was mcapable of forming the specific state of mind. In contrast to a successful insanity defense, however, the diminished capacity defense does not completely exculpate the defendant; she is convicted, but for a

8. See Henig, supra note 7; Tybor, supra note 7 .

9. See infra text accompanying notes 12-17.

10. See infra text accompanying notes 18-33.

11. See infra text accompanying notes 56-95.

12. Diminished capacity has also been referred to as partial responsibihity, diminished responsibility, and even partial insanity; each term has essentially the same meaning. See w. LaFave \& A. SCott, Handbook on Criminal Law 326 (1972). But see Arenella, The Diminished Capacity and Diminished Responsibility Defenses: Two Children of a Doomed Marriage, 77 COLUM. L. REv. 827 (1977) (Drawing distinction between diminished capacity and diminished responsibility).

13. See infra note 75 and text accompanying notes $73-76$.

14. As used herein psychosis is defined as:

profound, sweeping mental disorders characterized by partial or total loss of contact with, or distortion of reahity. Also characteristic are severe disturbances of perception, thought processes, feelings and behavior, retreat from or perversion of social relationships, and often a disintegration of personality structure, leading to the release of processes which ordinarily operate only unconciously.

M. Blinder, PSyChiatry IN THE EVERyday PRACTICE of Law, \$ 2.1 at 23 (2d ed. 1982) (emphasis in original). The term, therefore, is necessarily broad and encompasses many types of mental disorders. In most cases, however, a person who is psychotic will exhibit a mental state sufficiently impaired to satisfy any of the varying definitions of legal insanity. 
lesser offense. ${ }^{15}$

The classic use of the defense of diminished capacity is in inurder cases. To obtaim a conviction for first degree murder, the prosecution must establish that the defendant coolly and calmly planned the crime before acting. ${ }^{16} \mathrm{~A}$ defendant relying on a diminished capacity defense seeks to establish that she was incapable of such premeditation and deliberation because of a mental defect. If the defendant successfully establishes diminished capacity, she will be convicted of the lesser offense of second degree murder. ${ }^{17}$

\section{The Evidentiary Standards Applicable to the Use of EXPERT TESTIMONY CONCERNING PMS SYNDROME}

When the jury must evaluate factual issues beyond its common knowledge, the use of expert testimony is proper. ${ }^{18}$ As a practical matmatter cases involving the PMS syndrome will require expert testimony because the jury will probably not understand the defendant's testimony, or may not attach the proper importance to that testimony. Thus, whether the court will allow expert testimony to establish PMS syndroine will in effect determine whether the defendant will have sufficient opportunity to establish a diminished capacity defense.

To obtain admission of expert testimony, the defendant must first estabhsh that PMS syndrome, the subject of the expert's testimony, is

15. Jurisdictions that have considered the issue have exhibited three approaches to diminished capacity: (1) recognition of a diminished capacity defense where the crime charged requires a specific intent; (2) tecognition of a diminished capacity defense only where the crime charged has multiple degrees requiring different states of mind (mens rea); and (3) rejection of the diminished capacity defense entirely, allowing only an "all or nothing" insanity defense. Note, Dimin. ished Capacity-Recent Decisions and an Analytical Approach, 30 VAND. L. REV. 213, 214-28 (1977).

The Model Penal Code, although it abandons the specific/general intent dichotomy with respect to crimes, adopts a diminished capacity defense. Section 4.02(1) states: "Evidence that the defendant suffered from a mental disease or defect is admissible whenever it is relevant to prove that the defendant did or did not have a state of mind which is an element of an offense." MODEL Penal Code 8 4.02(1) (1962).

I6. See, eg., State v. Bowser, 214 N.C. 249, 199 S.E. 31 (1938); Cal. Penal Code 8189 (West Supp. 1982).

I7. See, eg., People v. Goedecke, 65 Cal. 2d 850, 857, 423 P.2d 777, 781-82, 56 Cal. Rptr. $625,629-30$ (1967) (en banc) (reducing first degree murder conviction to second degree after finding that the defendant's understanding of his act fell short of the mental state required for the crime of first degree murder); Battalino v. People, 118 Colo. 587, 199 P.2d 897 (1948); see also Comment, Deliberate Premeditation, Extreme Atrocity, and the Battered Child Syndrome-A New Look at Criminal Culpability in Massachusetts, 14 NEw ENo. L. REv. 812 (1979); Comment, The Doctrine of Diminished Capacity and the Use of Mental Impairment to Reduce Degree of Conviction in Massachusetts, Commonwealth v. Gould, 3 W. NEw ENG. L.J. 583 (1981).

18. See Dyas v. United States, 376 A.2d 827, 832 (D.C.), cert. denied 434 U.S. 973 (1977); MCCORMICK's HANDBOOK OF THE LAw OF EvidenCE \& 13, at 29-30 (E. Cleary 2d ed. 1972) [hereinafter cited as MCCormick]; Voorhis, Expert Opinion Evidence, 13 N.Y.L.F 651 (1968). 
beyond the knowledge of the average layman. The defendant must also show that the expert is qualified to testify and offer an opinion on the subject in question. ${ }^{19}$ If the expert is to base his opinion on a novel scientific principle or technique with which the court is unfamiliar, 20 most courts impose a further requirement: the proponent of the novel scientific evidence must establish that the theory or technique has achieved "general acceptance" in its scientific field. ${ }^{21}$

Frye v. United States, 22 a 1923 decision by the United States Court of Appeals for the District of Columbia, established the "general acceptance" standard. Because the Frye court did not explain or define "general acceptance," or cite any precedent for its holding, courts applying the Frye standard have had to define "general acceptance." These courts have also had to defend the Frye standard in the face of increasing criticisin from commentators. ${ }^{23}$ In response to this criticism,

19. See, eg., Dyas v. United States, 376 A.2d 827, 832 (D.C.), cert. denied, 434 U.S. 973 (1977) (citing MCCoRMICK, supra note 18, \& 13, at 29-30).

20. Certain scientific techniques are so widely accepted by courts that their reliability is judicially noticed. Exainples of such techniques include blood tests, ballistic tests, and fingerprinting analysis. Reed v. State, 283 Md. 374, 381, 391 A.2d 364, 367 (1978); see also Strong, Questions Affecting the Admissibility of Scientific Evidence, U. ILL. L.F. 1, 6.7 n.15 (1970).

21. See, e.g., Reed v. State, 283 Md. 374, 381, 391 A.2d 364, 367.68 (1978) (when the reliability of a new procedure cannot be judicially noted, the reliability of the procedure must be established, and the most widely used method of doing this is through a showing that a new technique has been "generally accepted" in its scientific 'field); Commonwealth v. Lykus, 367 Mass. 191, $204-$ 05, 327 N.E.2d 671, $678-79$ (1975) (admitting expert testimony based on use of voice spectography to identify a defendant's voice after concluding that the technique had achieved "generally acceptability" in its field).

22. 293 F. 1013 (D.C. Cir. 1923). The precise issue in Frye concerned the admissibility of evidence produced by a crude precursor to the modern polygraph. Although the opinion is only nine paragraphs long, it has become the landinark decision in the area. The actual language of the court is as follows:

Just when a scientific principle or discovery crosses the line between experimental and demonstrable stages is difficult to define. Somewhere in this twilight zone the evidential force of the principle must be recognized, and while courts will go a long way in admitting expert testimony deduced from a well-recognized scientific principle or discovery, the thing from which the deduction is made must be sufficiently established to have gained general acceptance in the particular field in which it belongs.

Id. at 1014 (einphasis added).

23. See, e.g., Giannelli, The Admissibility of Novel Scientific Evidence: Frye v. United States, a Half-Century Later, 80 CoLUM. L. REv. 1197, 1208-28 (1980); Strong, supre note 20, at 11-12. The most common criticism of the Frye standard is that it unnecessarily excludes relevant scientific evidence. This stems from Frye's insistence on general acceptance in an era in which scientific advances occur at a staggering pace. As stated by one commentator.

[I]n light of today's rapid increase of scientific specialization and progress, such a test presents one glaring problem: not only are the courts unable to determine the accuracy of the newest devices, but many of the experts themselves are unable to keep abreast of all the developing techniques. Thus, unless the courts choose to ignore a potentially useful source of information, a new system for determining the acciracy of these developinents inust be found.

Note, Evolving Methods of Scientific Proof, 13 N.Y.L.F. 677, 685 (1968); see also Boyce, Judicial Recognition of Scientific Evidence in Criminal Ceses, 8 UTAH L. REv. 313, 314 (1964). 
courts applying the Frye standard have advanced the following rationales in support of the test. First, the general acceptance standard ensures "that a minimal reserve of experts exist who can critically examine the .validity of a scientific determination in a particular case."24 Second, the Frye test promotes uniformity of decisionmaking. ${ }^{25}$ Third, the test eliminates time consuming hearings on the validity of new scientific techniques. ${ }^{26}$ The primary rationale advanced in support of Frye, however, is that it provides a means for ensuring the reliability of novel scientific evidence. ${ }^{27}$

Some courts refuse to follow Frye, and adopt instead the minority approach associated with Professor McCormick, one of Frye's early critics. ${ }^{28}$. Under McCormick's approach, once a party shows that the

. 24. United States v. Addison, 498 F.2d 741, 744 (D.C. Cir. 1974). The Addison court applied the "general acceptance" standard to voice spectography, a technique by which the identity of a person whose voice is recorded on tape may be determined. In support of its application of the Frye test, the Addison court stated:

[T] he Frye test protects prosecution and defense alike by assuring that a minimal reserve of experts exist who can critically examine the validity of a scientific determination in a particular case. Since scientific proof may in some instances assume a posture of mystic infallibility in the eyes of a jury ... the ability to produce rebuttal experts, equally Id. conversant with . . . a particular technique, may prove to be essential.

25. People v. Kelly, 17 Cal. 3d 24, 31, 549 P.2d 1240, 1244-45, 130 Cal. Rptr. 144, 148-49 (1976). The court in Kelly also addressed the issue of the admissibility of voice spectographic analysis. In support of Frye, the court stated: "[A] beneficial consequence of the Frye test is that it may well promote a degree of uniformity of decision. Individual judges whose particular conclusions inay differ regarding the reliability of particular seientific evidence, may discover substantial agreeinent and consensus in the scientific community." Id; see also Reed v. State, 238 Md. 374, 381, 391 A.2d 364, 367 (1978) ("the reliability of a scientific technique does not vary according to the circumstances of each case. . . [C]onsiderations of unifonnity and consistency of decision-making require that a legal standard or test be articulated").

26. Reed v. State, $283 \mathrm{Md}$. at $388,391 \mathrm{A.2d}$ at $371-72$ (1978). The Reed court argued that without the Frye test or its equivalent, a trial could degenerate into a protracted process of exainination and cross-examination of experts concerning a new technique. ld; accord State v. Cary, 99 N.J. Super. 323, 332, 239 A.2d 680, 684 (1968) ("It is not for the law to experiment but for science to do so.").

27. United States v. Addison, 498 F.2d 741, $743-44$ (D.C. Cir. 1974); Strong, supra note 20, at 14; Note, Evidence-Admissibility of Evidence-Frye Standard of "General Acceptance" for Admissibility of Scientific Evidence Rejected in Favor of Balancing Test, 64 CORNELL L. REv. 875, 881 (1979).

Commentators disagree on whether Frye in fact ensures the reliability of novel scientific cvidence. Compare Giannelli, supro note 23, at 1207-31 (problems in applying Frye far outweigh the reasons advanced for its use) with Note, supra, (Frye ensures the reliability of novel scientific evidence).

28. McCormick states that:

"General scientific acceptance" is a proper condition for taking judicial notice of scientific facts, but not a criterion for the admissibility of scientific evidence. Any relevant conclusions which are supported by a qualified expert witness should be received unless there are other reasons for exclusion. Particularly, probative value may be overborne by the familiar dangers of prejudicing or misleading the jury .... If the courts used this approach, instead of repeating a supposed requirement of "general acceptance" not else- 
proffered expert testimony is relevant, a court will admit the evidence unless it would, for example, prejudice or mislead the jury. ${ }^{29}$ Any disagreement within the scientific community concerning the reliability of the new technique or principle would go to the weight of the evidence, and would not affect its admissibility. ${ }^{30}$

Because the Frye standard requires "general acceptance" before novel scientific evidence may be admitted, it is a more conservative evidentiary standard than the relevancy approach associated with Professor McCormick. ${ }^{31}$ Therefore, although a court following Frye may

where imposed, they would arrive at a practical way of utilizing the results of scientific advances.

MCCORMICK, supra note $18, \S 203$, at 491 .

McCormick is, however, somewhat imconsistent. One commentator has pointed out that in the paragraph directly preceding the above passage, the novelty or want of general acceptance of a new scientific technique or principle is said to decrease the probative value of the evidence and increase the chances of misleading the jury. This follows the basic relevancy approach, and "suggests that novelty and want of general acceptance are integral parts of the relevancy analysis. In short, the admissibility of the evidence, not just its weight, is affected by lack of general acceptance." Giannelli, supra note 23, at 1233-34.

29. The Federal Rules of Evidence apparently support the relevancy approach. The "general acceptance" language of Frye cannot be found in any of the Rules. The only requirements for admitting scientific evidence are found in Rules 702 and 403 . Rule 702 states: "If scientific, technical, or other specialized knowledge will assist the trier of fact to understand the evidence or determine a fact in issue, a witness qualified as an expert . . may testify thereto . . . "The only significant limitation on this Rule is found in Rule 403, which excludes relevant evidence if its "probative value is substantially outweighed by the danger of unfair prejudice, confusion of the issues, or misleading the jury, or by considerations of undue delay, waste of time, or needless presentation of cumulative evidence."

Nevertheless, the federal circuit courts are sphit over whether the Federal Rules of Evidence abandon the Frye standard. See United States v. Williams, 583 F.2d 1194 (2d Cir.), cert. denied, 439 U.S. 1117 (1978); United States v. Baller, 519 F.2d 463 (4th Cir.), cert. denied, 423 U.S. 1019 (1975) (Frye test has not survived the enactment of the Federal Rules of Evidence). Contra United States v. Hendershat, 614 F.2d 648 (9th Cir. 1980); Umited States v. Brody, 595 F.2d 359 (6th Cir. 1979), cert. denied, 444 U.S. 862 (1980); United States v. McDaniel, 538 F.2d 408 (D.C. Cir. 1976) (contmuing to follow the Frye standard). Commentators also disagree as to whether the Federal Rules of Evidence abandon Frye. Compare Gianelli, supra note 23, at 1229 (presenting the argument that the Federal Rules have not abandoned Frye) with J. WEINSTEIN \& M. BERGER, 3 WEINSTEIN's EVIDENCE 9 702[03], at 702-16 (1981) [hereinafter cited as WeINSTEIN]. The latter states: "Rule 702's failure to incorporate a general scientific acceptance standard, and the Advisory Committee Note's failure to even mention the Frye case . . . should be regarded as tantamount to an abandonment of the general acceptance standard."

30. See United States v. Baller, 519 F.2d 463, 466 (4th Cir.), cert. denied, 423 U.S. 1019 (1975) ("ti]t is better to admit relevant scientific evidence in the same manner as other expert testimony and allow its weight to be attacked by cross-examination and refutation"); see also United States v. Williams, 583 F.2d 1194, 1200 (2d Cir. 1978), cent denied, 439 U.S. 1117 (1979).

31. Weinstein has captured the different philosophies exhibited by these two standards: "Instead of assuming inadmissibility unless the independently controlling standard of Frye is satisfied, the relevance approach favors admissibiity whenever the general conditions for the admissibility of evidence have been nuet." 3 WEINSTEIN, supra note 29, $1702[03]$, at 702-21. 
admit expert testimony concerning PMS syndrome, 32 the defendant will be more likely to have such testimony admitted in a jurisdiction that follows Professor McCormick's approach. ${ }^{33}$

\section{.III. THE $F_{R Y E}$ STANDARD}

\section{A. Determining Whether Frye Applies.}

It is not clear that courts following Frye will choose to apply the "general acceptance" standard to expert testimony on PMS syndrome. Courts have applied Frye primarily to expert testimony regarding evidence obtained through the use of a inechanical device or instrument. ${ }^{34}$ Examples include polygraphs, ${ }^{35}$ voice spectrographs, ${ }^{36}$ neutron activation analyses, ${ }^{37}$ and gunshot residue analyses by scanning electron microscopes. ${ }^{38}$ In contrast, courts have not subjected expert testimony based on psychiatric or psychological science to the rigors of the "general acceptance" standard. One commentator noted this difference in approach and could offer only this explanation:

[T] his form of evidence-which purports to be scientific, although admittedly more "social" in background - has been more readily and easily accepted by courts than the more objective "physical" evidence from scientific devices. The rule of the Frye case has not been applied to this field, apparently because the evidence in opinion form is not tantamount to being the result of a device or mechanical

Some courts have considered the conservative nature of the Frye standard one of its most worthwhile features. See People v. Kelly, 17 Cal. 3d 24, 31-32, 549 P.2d 1240, 1245, 130 Cal. Rptr. 144, 149 (1976); see also United States v. Addison, 498 F.2d 741, 743-44 (D.C. Cir. 1974).

32. See infra notes $40-49$ and accompanying text.

33. See infra notes $89-93$ and accompanying text.

34. See State ex rel. Collins v. Superior Courh, 132 Ariz, 180, 198-99, 644 P.2d 1266, 1283-85 (1982) (original and supplemental opinion) (applying Frye to the issue of the admissibility of testimony from a witness whose memory was hypnotically refreshed, after noting that hypnosis, unlike other scientific techniques to which Frye has been applied, does not involve data obtained from physical tests); State v. Hurd, 86 N.J. 525, 536, 432 A.2d 86, 91 (1981) (noting that the Frye standard has usually been applied to results of "physical tests such as radar.").

35. See United States v. Alexander, 526 F.2d 161, 163-64 (8th Cir. 1975) (rejecting polygraph evidence); People v. Anderson, 637 P.2d 354, $358-59$ (Colo. 1981) (rejecting polygraph evidence).

36. See People v. Kelly, 17 Cal. 3d 24, 549 P.2d 1240, 130 Cal. Rptr. 144 (1976) (rejecting voiceprint analysis); Reed v. State, 283 Md. 374, 391 A.2d 364 (1978) (rejecting voiceprint analysis); People v. Tobey, 401 Mich. 141, 145-48, 257 N.W.2d 537, 538-40 (1970) (rejecting voiceprint analysis).

37. See United States v. Brown, 557 F.2d 541, 554-58 (6th Cir. 1977) (rejecting neutron activation analysis of hair samples after applying variant of Frye test that equates general acceptance with reliability); United States v. Stifel, 433 F.2d 431, $438-41$ (6th Cir. 1970), cert. denied, 401 U.S. 994 (1971) (admitting evidence based on neutron activation analysis afler finding the technique was generally accepted).

38. See People v. Palmer, 80 Cal. App. 3d 239, 250-55, 145 Cal. Rptr. 466, $471-74$ (1978) (use of a scanning electron microscope to identify particles is generally accepted). 


\section{instrument. ${ }^{39}$}

Frye, however, has recently been applied to novel scientific evidence not involving the measurement of physical data. Courts have evaluated the admissibility of expert testimony on battered wife syndroine (BWS) by applying the Frye "general acceptance" standard.40 As with PMS syndrome, the proffer of BWS evidence confronts a court with novel scientific evidence that does not involve the use of inechanical aids. BWS has been identified through studies of women who have been repeatedly beaten by their husbands or boyfriends. These studies attempt to explain the psychopathology of the battering relationship and the seemingly irrational response of women in these relationships.41 The expert decides whether a particular individual suffers from BWS by evaluating the woman's history of battering in light of what past studies have identified as instances of BWS.42

Many courts, in deciding whether or not to allow testimony concerning BWS, have applied what is in effect the "general acceptance" standard of Frye. Although these decisions have not reached uniforin results, the primary disagreement between courts is whether "the study of the battered woinan syndroine is an area sufficiently developed to permit an expert to assert a reasonable opmion."43

39. Boyce, Judicial Recognition of Scientijic Evidence in Criminal Cases, 8 UTAH L. REv. 313, 324 (1962-1964). A more recent commentator has suggested that the Frye standard ought to be applied to psychological or psychiatric testimony by experts. According to this commentator, courts have focused on the qualifications of the particular expert witness rather than the underlying rehabihty of the scientific principles on which the expert bases his opinions, thus judicially noticing the reliability of psychological or psychiatric testimony by experts. Comment, The Psychologist as Expert Witness: Science in the Courtroom, 38 MD. L. REv. 539 (1979).

40. A defendant usually seeks to introduce expert testimony on battered wife syndrome (BWS) as part of a claim of self defense to a murder or assault charge. The defendant introduces evidence of BWS to show that she was a battered woman, that she did not end her marriage or relationship because she suffered from a condition known as "learned helplessness," and that she reasonably feared that she was about to be killed or suffer great bodily harm when she either killed or assaulted her husband or boyfriend. See, e.g., Ibn-Tamas v. Umited States, 407 A.2d 626 (D.C. 1979); Hawthorne v. State, 408 So. $2 d$ 801, 805-06 (Fla. Dist. Ct. App. 1982); State v. Thomas, 66 Ohio St. 2d 518, 423 N.E.2d 137 (1981); L. WALKER, THE BATTERED WOMAN 42-54 (1979); see also Note, Partially Determined Imperfect Self-Defense: The Battered Wife Kills and Tells Why, 34 Stan. L. REv. 615 (1982). But see State v. Baker, 120 N.H. 773, 424 A.2d 171 (1980) (state offered evidence that the defendant's wife had suffered from BWS to rebut the defendant's insanity defeuse to the cliarge of attempted murder of his wife).

41. Sce L. WALKER, supra note 40 , at $42-54$. Dr. Walker, a clinical psychologist, is the preemment expert in this field and is often called to testify for a defendant who claims to suffer from BWS. See, e.g., Hawthorne v. State, 408 So. $2 d 801$ (Fla. Dist. Ct. App. 1982).

42. See Ibn-Tamas v. United States, 407 A.2d 626, 634, 637 (D.C. 1979) (appellate court applying a variant of Frye found that the trial court erred in refusing psychologist's testimony on BWS).

43. Hawthorne v. State, 408 So. 2d 801, 805 (Fla. Dist. Ct. App. 1982) (citing Dyas v. United States, 376 A.2d 827, 832 (D.C.), cert. denied, 434 U.S. 973 (1977)). 
For example, in Ohio v. Thomas ${ }^{44}$ the Ohio Supreme Court rejected expert testimony on BWS, stating that "Battered Wife Syndrome' is not sufficiently developed, as a matter of commonly accepted scientific knowledge to warrant testimony under the guise of expertise," 45 and that "no general acceptance of the expert's particular methodology has been established."46 Likewise, in Buhrle v. State ${ }^{47}$ the Wyoming Supreme Court held expert testimony on BWS madmissible, emphasizing that the "acceptance or recognition of the phenomenon is largely limited to people who are actively engaged in the research [of BWSI." 48 In other words, in the court's opinion, BWS had not attained a sufficient degree of acceptance in the scientific community to warrant the admission of expert testimony. In Ibn-Tamas $v$. United States, the Court of Appeals for the District of Columbia, however, when faced with expert testimony nearly identical to that in Thomas and Buhrle, applied a version of Frye's "general acceptance" standard and concluded that the trial court had erred in excluding expert testimony on BWS. 49

Cases involving BWS are only one example of courts applying the "general acceptance" standard to novel scientific evidence not involving mechanical aids or devices. Courts have also applied the "general acceptance" standard when a party has proffered testimony of a witness whose memory has been refreshed through hypnosis, ${ }^{50}$ when a defend-

44. 66 Ohio St. 2d 518, 423 N.E.2d 137 (1981).

45. Id at 522,423 N.E.2d at 140 .

46. Id at 521,423 N.E.2d at 140 .

47. 627 P.2d 1374 (Wyo. 1981).

48. Id at 1377. Some courts have concluded that Frye's "general acceptance" standard is satisfied even if "general acceptance" exists only among those actively engaged in researching or studying the new technique or principle. See infra note 59.

49. 407 A.2d 626, 638 (D.C. 1979). Although Ibn-Tamas cites Frye and applies it to the inquiry of whether an expert can assert a reasonable opinion, it does so in a manner inconsistent with prior case law. The court states that in applying the "general acceptance" standard the relevant inquiry is whether the expert's "methodology for identifying and studying women has [gained] general acceptance-not whether there is, in addition, a general acceptance of the battered woman concept derived from that inethodology." Id This application of frye is incorrect. Frye is not directed at whether a scientist has followed generally accepted practices in his research. If this were true, phrenologists and astrologers could persuasively argue that their testiunony based on their work is admissible. All they would need to show is that they followed properly controlled research procedures in reaching their conclusions.

Other courts have accepted expert testimony on BWS without mention of the general acceptance standard. See, e.g., Smith v. State, 247 Ga. 612, 277 S.E.2d 678 (1981); Maine v. Anaya, 438 A.2d 892 (Mc. 1981).

50. See State ex rel. Collins v. Superior Court, 132 Ariz. 180, 644 P.2d 1266 (1982) (noting that Frye had been applied in most cases to data obtained through physical tests); State v. Mack, 292 N.W.2d 764, 769 (Minn. 1980) (specifically rejecting argument that Frye does not apply where proffered evidence does not consist of resnlts froun a inechamical device); State v. Hurd, 86 N.J. 525, 432 A.2d 86 (1981); Commonwealth v. Nazarovitch, 496 Pa. 97, 436 A.2d 170 (1981). 
ant has sought to introduce expert testimony on the unreliability of eye witnesses, ${ }^{51}$ when the defendant has tried to introduce expert testimony on psycholinguistics, ${ }^{52}$ and when the prosecution has tried to introduce expert testimony on rape trauma syndroune to negate a defendant's argument that a rape victim had consented to sexual intercourse with him.53 These cases indicate that a mere lack of "hard" physical data does not prevent a court from applying the Frye test to novel scientific evidence such as PMS syndrome.

Applying the Frye standard to PMS cases is logically sound. The standard provides the court with a convenient franework for evaluating a proffer of expert testimony on PMS syndrone. More importantly, the requirement of general acceptance ensures the reliability of novel scientific evidence such as evidence of PMS syndrome. ${ }^{54}$ Thus, the Frye test is well suited to the issue of whether a court should admit expert testimony on PMS syndroine.

\section{B. Applying the Frye Standard to Cases Involving PMS Syndrome.}

Once a court decides to use the Frye test to evaluate a proffer of expert testimony on PMS syndroune, it must apply the Frye standard. ${ }^{55}$ The court inust first define the relevant scientific community. Second, it must define the concept or theory that the community is to accept or reject. Finally, the court must determine whether the community ac-

51. See United States v. Fosher, 590 F.2d 381, 383 (Ist Cir. 1979) (citing Frye as one standard for evaluating reliability but also citing more flexible "relevancy" approach and applying balancing approach of Federal Rules of Evidence).

52. See United States v. Hearst, 412 F. Supp. 893,895 (N.D. Cal. 1976) (affirming trial court decision to exclude expert testimony based on psycholinguistics that would have indicated that defendant's writings or utterances were authored by someone else and stating: "It is not inconceivable that in the near future the science of psycholinguistics will have achieved such general acceptance among psychological and scientific authorities as to justify courts of law in admitting expert testimony on this subject.").

53. See State v. Marks, 31 CRIM. L. ReP. (BNA) 2388 (July 16, 1982) (applying Frye test in choosing to admit testimony on rape trauma syndrome even though use of general acceptance standard in Kansas had previously been applied only to physical scientific evidence).

54. See supra note 27 and accoinpanying text.

55. In applying Frye, courts have often reached different results when presented with similar, if not identical, scientific evidence. This has occurred, in large measure, because the Frye court failed to explain the standard "general acceptance in the particular field in which it belongs." Frye, 293 F. at 1014. The Frye court also failed to cite any precedent for its holding. Thus, the task of putting fiesh on the bones of the Frye court's language has fallen upon courts that have since adopted the standard. Lack of uniformity is predictable in such circumstances. The conflicting results reached by courts regarding the admissibility of expert testimony on voice spectography is a striking example of this lack of uniformity. Some courts have admitted, while others have excluded, expert testimony based on the technique. See infra note 59. 
cepts or rejects the concept or theory. ${ }^{56}$

Defining the relevant scientific community is not always an easy task. Many new scientific principles fall into more than one scientific field, ${ }^{57}$ thereby making it difficult to assign a new principle or theory to a particular discipline. PMS syndrome is no exception. Although it falls within the general field of medical science it encompasses inany specialities within medicine. For example, psychiatry, gynecology, endocrinology, and neurology are all fields of study that, to one extent or another, have a role to play in the study of PMS syndrome..$^{58}$

In choosing a particular scientific field a court has wide latitude. Generally, the more broadly a court defines the relevant scientific coinmunity, the more difficult it is to gain admission of the expert testimony based on the novel scientific principle. ${ }^{59}$ Thus, if a court chooses the

56. See, e.g., State ex rel. Collins v. Superior Court, 132 Ariz 180, 644 P.2d 1266 (1982); Commonwealth v. Lykus, 367 Mass. 191, 202-03, 327 N.E.2d 671, 677-78 (1975); see also Giannelli, supra note 23, at 1208-19.

57. Voice spectography, for example, involves the scientific disciplines of anatomy, physics, psychology, and linguistics. People v. King, 266 Cal. App. 2d 437, 456, 72 Cal. Rptr. 478, 490 (1968).

The inability to pigeonhole certain scientific principles often leads to their exclusion under Frye because it is difficult to establish the qualifications of an expert witness. However, with the passage of time and the increasing number of experts familiar with a particular teclnique or principle, Frye can be satisfied. As noted by one commentator: "The critical factor seems to be whether solne scientific profession-although not the one to which the principle is indigenoushas put the principle to some use of its own, thus affording a thorough empirical testing of the principle." Strong, supra note 20, at 12.

58. See generally various studies cited in Reid \& Yen, supra note 1.

59. The Nalline test, which is used to detect the presence of narcotics in an individual's bloodstream, and voice spectography, which is used to match recordings of a defendant's voice for identification purposes, provide examples of the critical role played by the definition of the relevant scientific community in a court's decision to either adinit or exclude novel scientific evidence. In People v. Williams, 164 Cal. App. 2d Supp. 858, 331 P.2d 251 (App. Dep't Super. Ct. 1958), the issue was whether to admit expert testimony based on the newly developed Nalline test. Had the court applied the Frye test literally, general acceptance could not have been shown. The proponent of the evidence, the prosecution, conceded that the general medical profession would be unfamiliar with the test. The courh, however, chose a narrow subspecialty of the medical profession as the relevant scientific community. The court required general acceptance of the test by "those who would be expected to be familiar with its use," stating that "ii]n this age of specialization more should not be required." Id. at 862,331 P.2d at 254 .

Courts presented with expert testimony based on voice spectrography have not always de. fined the relevant scientific community similarly. The result has been the admission of such testimony in some jurisdictions and its exclusion in others. In People v. Rogers, 86 Misc. 2d 868, 385 N.Y.S.2d 228 (Sup. Cl. 1976), for example, the court admitted testimony based on voice spectograply by, in effect, limiting the relevant scientific community to a single researcher in the field. In admitting the expert testimony, the court found that the results obtained by this single researcher adequately vouched for the reliability of voice spectography. Id. at 874-82, 385 N.Y.S.2d at 233-37; see also Hodo v. Superior Court, 30 Cal. App. 3d 778, 785-89, 106 Cal. Rptr. $547,551-53$ (1973) (relying primarily on testimony of a single expert in concluding that voice spectography is generally accepted); Commonwealth v. Lykus, 367 Mass. 191, 205, 327 N.E.2d 
general area of medicme as the relevant community, it is unlikely that it will find that PMS syndrome is generally accepted. Few physicians can speak authoritatively about PMS syndrome because it has only recently been identified and studied with any regularity. ${ }^{60}$

There is precedent, however, for confining the relevant scientific community to those researchers and clinicians who have studied PMS syndrome and who are familiar with the current scientific literature on PMS syndrome. ${ }^{61}$ The pitfall of this approach is that it may narrow the field so inuch that the court cannot obtain an unbiased opinion, thereby nndermining the overriding rationale of Frye-assurance of the reliability of novel scientific evidence.62 There is, however, an increasing nuniber of physicians, clinical psychologists, and other interested scientists who, either in person or through their published writings, could

671,678 (1975) (admitting testimony based on voice spectography after quoting with approval the Williams language stating that general acceptance should only be required from those expected to be familiar with the use of a new technique).

Other courts, that have not so narrowly defined the relevant scientific community, have rejected evidence based on voice spectography. The court in People v. Tobey, 401 Mich. 141, 257 N.W.2d 537 (1977), held that voice spectography had not gained general acceptance in the scientific community. Central to the court's holding was its position that "general scientific recognition nay not be established without the testimony of 'disinterested and impartial experts,' 'disinterested scientists whose livelihood was not intimately connected with' the new technique." Id. at 145, 257 N.W.2d at 539 (citations omitted). In People v. Kelly, 17 Cal. 3d 24, 549 P.2d 1240, 130 Cal. Rptr. 144 (1976), the court rejected evidence based on voice spectography after pointing out that the prosecution's expert on voice spectography admitted that general acceptance of the technique was restricted to "those persons . . . actually involved in voiceprint work . . . primarily [as] voiceprint examiners . . . "Id. at 37, 549 P.2d at 1248, 130 Cal. Rptr. at 152. These divergent results highlight how critical the definition of the scientific commumity is in deciding whether novel scientific evidence satisfies the Frye standard for admissibility.

These results, however, may only refiect a result-oriented jurisprudence. Those courts wishing to admit a certain type of novel scientific evidence will be satisfied to rely on the statements of a few well placed experts who will attest to the rehability of the evidence. In this regard, one cominentator notes: "Instead of using Frye as an analytical tool to decide whether novel scientific evidence should be admitted, it appears that many courts apply it as a labei to justify their own views about the rebiability of particular forensic techniques." Giannelli, supra note 23, at 1221; see also Korn, Law, Fact and Science in the Courts, 66 CoLUM. L. REv., 1080, 1098 (1966) (the "law's reference to science" merely creates a "veneer of scientific determinism to decisions that really turn on policy considerations to which the scientific referent bears little relation.").

60. Cominentators and courts often criticize the Frye test for barring the admission of new scientific evidence. Extremely novel techniques can rarely satisfy the general acceptance standard once the relevant scientific community is defined beyond those imtimately connected with research concerning the new principle or technique. See supra note 23.

61. See, eg., People v. Williams, 164 Cal. App. 2d Supp. 858, 862, 331 P.2d 251, 254 (App. Dep't Super. Ct. 1958) (general acceptance ouly required of those expected to be faniliar with the new technique); see also Hodo v. Superior Court, 30 Cal. App. 3d 778, 785-89, 106 Cal. Rptr. 547, $551-53$ (1973) (relying on single expert to establish general acceptance); Cominonwealth v. Lykus, 367 Mass. 191, 203, 327 N.E.2d 671,678 (1975) (following Williams in defining relevant scientific cominunity).

62. See Giannelli, supra note 23 , at 1209-10. 
provide a court with a diverse pool of experts on PMS syndrome. ${ }^{63}$ Thus, a court could define the scientific community to include not only experts with extensive first-hand knowledge about PMS syndrome, but also to include cnough other experts ${ }^{64}$ to prevent the court from relying on the opinions of a few isolated scientists.

Having defined the scientific community, a court must determine precisely what Frye requires to be generally accepted. More specifically, the court must decide whether Frye requires general acceptance of the theory underlying a new tcchnique or principle or whether it requires acceptance of only the technique or principle as applied. ${ }^{65}$ In the context of PMS syndrome, the court inust decide whether the defendant inust show that the cause of PMS syndrome as well as its potential inanifestations in an individual have been generally accepted. Notwithstanding the optimistic statements of a few early commentators, 66 a consensus is only now conerging on the cause of PMS syndroine. The most up-to-date research identifies PMS syndrone as the result of a neuroendocrine disorder.67 Recently, however, two researchers in the field, aftcr reviewing all the pertinent hiterature, could only conclude that, "[t]o date no one hypothesis has adequately explamed the constellation of syinptoins coinposing . . PMS."68

In applying the Frye standard, however, a court should not focus on whether there is agreement as to the cause of PMS syndrome. The

63. See, eg;, Reid \& Yen, supra note 1, at 97-104 (reviewing the literature on PMS syndroine while proposing to redefine the pathophysiology of PMS syndrome).

64. This group would forsecably include gynecologists, psychologists, and psychiatrists familiar with current developments concerning PMS syndroine even though these people might not have extensive first-hand clinical experience with the syndrome.

65. Giannelli, supra note 23, at 1211. The National Research Council takes the position that Frye requires "gencral acceptance" of both the underlying theory and the technique. NATIONAL Research Council, ON The Theory and Practice of Voice Identification 41 (1979). Wright \& Graham have stated that decisions applying Frye hinge on acceptance of the underlying theory. 22 C. Wright \& K. Graham, Federal Practice and Procedure: Evidence, \& 5168 (1978). Giannelli finds that courts have rarely considered the issue. See Giannelli, supra note 23, at 1212. But see Ibn-Tamas v. United States, 407 A.2d 626, 638 (D.C. 1979).

Some courts have approached general acceptance in a different manner. These courts focus on the "reliability" of the new technique or principle. D'Arc v. D'Arc, 157 N.J. Super. 553, 385 A.2d 278 (1978); People v. Collins, 94 Misc. 2d 704, 405 N.Y.S.2d 365 (1978). This approach bypasses the issue of general acceptance because the "reliability of a scientific technique could bo established notwithstanding its lack of general acceptance in the scientific community." Giannelli, supra note 23, at 1220.

66. See infra note 72 and accompanying text.

67. Reid \& Yen, supra note 1, at 96-97.

68. Id at 97. The difficulty in identifying the cause of PMS syndroine is that, as with inany liuman disorders, an imponderable nuniber of variables may contribute to its onset. For this reason medical experts are often, to the consternation of judges and lawyers alike, unable to recite with precise certainty the cause of a particular disease or ailment. 
important legal issue is whether there is "general acceptance" among experts that PMS syndrome can impair mental function to a degree sufficient to negate the specific state of mind required for certain crimes. To require a defendant to establish that there is also "general acceptance" of the cause of PMS would be unfairly burdensome. For purposes of the Frye standard, therefore, a court should require only that a proponent of expert testimony on PMS syndrome establish the "general acceptance" of the scope and severity of the potential symptoms, and not the underlying cause of PMS syndrome.

Finally, the court must determine whether the relevant scientific cominunity, as defined by the court, generally accepts the claim that PMS syndrome can impair mental function im a legal sense. ${ }^{69}$ To answer this question a court may rely on more than the in-court testimony of experts. ${ }^{70}$ In the past, courts have relied heavily on the scientific writings of experts concerning the novel scientific evidence in issue..$^{71}$

1. The Insanity Defense. There is hittle evidence that PMS syndrome alone produces psychotic behavior (insanity) in females. ${ }^{72} \mathrm{Re}-$ searchers who have examined the question have concluded that PMS

69. Courts have not decided what percentage of experts must accept the novel scientific evidence as accurate; instead, the courts offer rather vague statements. One court, for example, stated that "conclusiveness" is not required. Umited States v. Stifel, 433 F.2d 431, 438 (6th Cir. 1970), cert. denied, 401 U.S. 994 (1971). The Massachusetts Supreme Court stated that the "Frye standard does not require unanimity of view, only general acceptance; a degree of scientific divergence is inevitable." Commonwealth v. Lykus, 367 Mass. 191, 204 n.6, 327 N.E.2d 671, 678 n.6 (1975). The Minnesota Supreme Court has required a "widely" shared view. State v. Mack, 292 N.W.2d 764, 768 (Minn. 1980).

70. See, e.g., Reed v. State, 283 Md. 374, 380, 391 A.2d 364, 367 (1978).

71. See Commonwealth v. Lykus, 367 Mass. 191, 204, 327 N.E.2d 671, 678 (1975); People v. Rogers, 86 Misc. 2d 868, 873, 385 N.Y.S.2d 228, 232 (Sup. Ct. 1976); see also Giannelli, supra note 23 , at $1217-18$.

A court might also rely on past court decisions to aid in ascertaining whether general acceptance exists. In the case of PMS syndrome this avenue of inquiry would be profitless: no court to date has issued an opinion on the matter.

72. Oleck, an early commentator, contended that a PMS syndrome induced temporary insanity could be proved by objective scientific tests. Oleck asserted that PMS syndrome is closely linked to periodic episodes of hypoglycemia and can therefore be identified by a simple laboratory test. Oleck, supra note 7, at 494. See also Stewart, Psychotic Aspects of Premenstrual Tension, 6 Clev.-MAR. L. Rev. 410 (1957), in which the author, then a student at the sanue school as Oleck, inade a sinilar argument. Both Oleck and Stewart took a rather crusading attitude towards establishing PMS syndrome as a "legal fact." Stewart, however, whose article appeared four years after Oleck's, was no longer able to state categorically that the presence of PMS syndrome could be proved before or after the event. Stewart, however, did state that:

[t] hose entrusted with administering justice must be extremely prudent in accepting novel principles which the test of time may prove to be imcorrect. Conversely the law inust also battle the danger of being overcautious and impeding true progress. . . It is to be hoped that this innate conservatism of the legal profession will not prevent lawyers from keeping open minds as to the acceptance of premenstrual tension as a legal fact. 
syndrome alone cannot cause recurrent cyclical psychosis. ${ }^{73}$ In 1953 , for instance, one clinician, after noting that PMS syndrome often produces striking personality changes, commented that "singular symptoms [such] as evanescent psycliotic episodes and epilepsy must be carefully scrutinized and the patient regarded as having a inore serious illness than premenstrual tension." 74 Another researcher, in 1957, after reviewing the literature to date, concluded that the "concept of a menstrual psychosis can now be abandoned. No convincing evidence has been produced to sliow that such an entity exists."75 More recent findings have not established a causal connection between PMS syndrome and psychosis. ${ }^{76}$ Thus, a temporary insanity defense based on PMS syndrome is not likely to succeed.

2. The Diminished Capacity Defense. This is not to suggest, lowever, that PMS syndrome is legally insignificant; it may be relevant to prove diminished capacity. Many researchers have concluded that PMS syndrome may, along with other factors, produce striking personality changes in patients. One researcher states:

That the endocrine changes themselves may play a part in the causation of psychosis remains a possibility which has not been adequately deinonstrated. It is possible to conceive of a psychic disturbance which results in interference with endocrine function. The latter might then either perpetuate the original disturbance or cause psychotic states. ${ }^{77}$

Another researcher concludes that PMS syndrome eannot be shown to produce "temporary insanity," but suggests that it inight be used to

And this is said with full awareness of the fact that clear medical proof of its exact nature is yet to be established.

Id at 426-27. Oleck's view, however, has been discredited. More recent research has dismissed the link between hypoglycemia and PMS syndrome. Reid \& Yen, supra note 1, at 88. Hence it is not possible to say, as Oleck did, that the link between temporary insanity and PMS syndrome falls within the "area of provable fact." Oleck, supra note 7, at 492.

73. See Gregory, The Menstrual Cycle and Its Disorders in Psychiatric Patients, 2 J. of PsyChosomatic ReSEARCh 61, 75 (1957); Perr, supra note 1, at 217.

74. Israel, The Clinical Pattern and Etiology of Premenstrual Tension, 166 lNT'L REC. OF MED. 469, 471 (1953).

75. Gregory, supra note 73, at 75.

A more recent report in the medical literature has documented psychosis in relation to the menstrual cycle. The report pointed out, however, that the form of psychosis identified was not related to PMS syndrome. "Two out of our seven cases showed the somatic symptoms of premenstrual tension. . . . But the psychosis in question here shows a different feature appareatly from premenstrual tension. We are dealing with mental illness aligned with the menstrual cycle and not pre-Inenstrual tension associated with psychotic episodes." Endo, Daiguji, Asano, Yamashita \& Takahashi, Periodic Psychosis Recurring in Association with Menstrual Cycle, 39 J. CLIN. PsYcHLATRY 456, 461 (1978).

76. Clare, 4 Current Med. Research \& Opinion 23-28 (1976).

77. Gregory, supra note 73, at 75. 
establisl mitigating circumstances. ${ }^{78}$

More recent researcli by d'Orban and Dalton, two of the leading experts in the field, has established that a statistically significant percentage of females who commit violent crimes do so during the paramenstruum. ${ }^{79}$ PMS syndrome, therefore, nay well influence the actions of wounen who exhibit recurrent criminal behavior only during their premenstrual or paramenstruun periods. They caution, however, that "in interpreting the criminological significance of these findings, it would be wrong to assume that women in general are more likely to commit violent crime during certain phases of their inenstrual cycle; [instead, they postulate that] the psychological effects of menstruation may act as a triggering factor to aggressive behavior in some women who also show evidence of emotional instability at other times."80 This view is consistent with the findings of earlier researchers who concluded that PMS syndrome alone does not produce psychotic behavior. 81

Of greater significance is Dalton's documentation of the case histories of three women in England. Charged with the crimes of manslaughter, arson, and assault, respectively, each successfully pleaded either diminished responsibility or mitigation, based on PMS syndrome. ${ }^{82}$ The behavior of these women was not psychotic. Dalton diagnosed each of thein as suffering from PMS syndrome. She found that each had histories of cychically violent behavior related to menstruation. All came from families with no history of criminal behavior. None exhibited the somatic symptoms often associated with PMS syndrome. They all acted alone, and incarceration did not deter then frown further violent behavior. Dalton based her diagnosis entirely on "the cyclical relationship of their crimes as recorded" in police and

78. Perr, supra note 1 , at 218.

79. d'Orban \& Dalton, supra note 4; see also Dalton, Menstruation and Crime, 2 BRIT. MED. J. 1752 (1961); Morton, Additon, Addison, Hunt \& Sullivan, A Clinical Study of Premenstrual Tension, 65 AM. J. OBSTET. AND GYNECOL. 1182 (1953).

These studies have not, however, established any precise causal connection between PMS syndrome and crime. d'Orban \& Dalton report that only two of the women in their study were aware of any connection between their crimes and their menstrual cycle and that less than a quarter exhibited somatic symptoms. This led d'Orban and Dalton to conclude:

[I]t appears that most women who commit violent crime during the paramenstruuin do not complain of subjective premenstrual tension symptoms and their only 'symptom' may be an offence of violence or increased aggression during this period. Perhaps too much emphasis has been placed on premenstrual tension symptoms as an actiological factor in female crime.

d'Orban \& Dalton, supro note 4, at 358 (emphasis added).

80. d'Orban \& Dalton, supra note 4, at 358.

81. See supra note 75 and text accompanying notes 73-76.

82. Cyclical Criminal Acts, supra note 6, at 1071. 
prison records. Each woman was treated with natural progesterone therapy, and each remained free of continued episodes of misbehavior as long as she followed her treatment regimien. ${ }^{83}$ These three case studies lend some support to the hypothesis that PMS syndrome causes criminal behavior in some woinen.

Dalton adinonished, however, that "[w]e must remain suspicious of women who plead that premenstrual syndrome is a reason for mitigation or diminished responsibility." 84 She pointed out that the etiology of the syndrome is still unclear and that "good diagnostic proof is still necessary." 85 In this regard, the following statement by Greene and Dalton, made in 1957, is still valid:

Unfortunately, there is no test to assist the diagnosis of premenstrual syndrome . ... [T] The recognition of this syndrome must depend on the intelligence of the patient, or her doctor. The only positive diagnosis of premenstrual syndrome can be made by recording on a calender the relationships of symptoms to menstruation. ${ }^{86}$

These studies and surveys constitute the literature on PMS syndrome as it directly relates to criminal behavior. The numerous studies on the physical and psychological synnptoms that occur with PMS syndrome ${ }^{87}$ have been limited in scope, usually correlating the incidence of neuroses or affective disorders with PMS syndrome. ${ }^{88}$ No studies, other than those cited, have attempted to find a causal connection between PMS syndrome and criminal behavior or have tried to evaluate, from a legal perspective, the extent to which PMS syndrome might impair mental function.

In summary, PMS syndrome by itself does not appear to produce psychotic behavior that would support a plea of insanity. PMS syndrome may trigger or exacerbate underlying disorders, and it may be related to cyclically recurrent criminal behavior, although it has not been established whether it is the underlying cause of such behavior. The research in the field, therefore, indicates that a claim of temporary insanity induced by PMS syndrome would not satisfy the Frye "general acceptance" standard.

83. $I d$.

84. Id. at 1071.

85. Id.

86. Greene \& Dalton, Discussion on the Premenstrual Syndrome, 48 Proc. RoYal Soc'Y MED: 337, 339 (1954).

87. See generally studies cited in Reid \& Yen, supra note 1.

88. See, eg., Abramowitz, Baker, \& Fleischer Onset of Depressive Psychiatric Crises and the Menstrual Cycle, 139 Am. J. Psychintry 475 (1982). Blank, Goldstein, \& Chatterjie, Pre-Mcnstrual Tension and Mood Change, 25 CAN. J. PsYchiatry 577 (1980); Golub, The Magnitude of Pre-Menstrual Anxiety and Depression, 38 Psychosmatic MED. 4 (1976); Gregory, supra note 73. 
The research, however, does not address the precise issue of whether PMS syndrome can impair mental function to such a degree that a defendant could not form the specific state of mind required for certain crimes. Dalton's research might support such a claim. What other experts might testify to on that particular issue, however, cannot be known. Thus, one cannot state categorically whether the Frye test would require the admission or exclusion of expert testimony on PMS syndrome offered to support a claim of diminished capacity.

\section{The Relevancy Approach AND PMS Syndrome}

As discussed earlier, not all courts apply the Frye standard to novel scientific evidence. Under Professor McCormick's $\mathrm{s}^{89}$ approach, expert testimony on novel scientific evidence such as PMS syndrome is admissible when it is shown to be relevant, absent substantial other reasons for exclusion. ${ }^{90}$

Evidence is relevant if it tends to make "the existence of any fact that is of consequence to the determination of the action more probable or less probable than it would be without the evidence."91 The McCormick approach requires a balancing test: the greater the relevancy of expert testimony on PMS syndrome, the less the chance it will be excluded for reasons such as prejudicing the jury. In the context of a teinporary insanity defense the relevance of expert testimony on PMS syndrome would be low. There is little or no support for the view that PMS syndrome can induce psychosis. ${ }^{92}$ Thus, even under the liberal approach of McCormick sucli testimony should not be admitted when offered to support a temporary insanity defense. In diminished responsibility cases, however, the issue is whether the defendant was capable of forming the specific state of mind required for the crime. Expert testimony that the defendant suffered from PMS syndrome and thus could not form the requisite state of mind would certainly be relevant. The court would exclude the testimony only if it were slown that the relevancy of the evidence was substantially outweighed by the danger of unfair prejudice, confusion of the issues, misleading the jury, or by considerations of undue delay, waste of time, or needless presentation of cumulative evidence. ${ }^{93}$

89. See supra notes $28-30$ and accompanying text.

90. Other reasons for exclusion include: "prejudice, confusion of the issues, misleading the jury, or consideration of undue delay, waste of time, or needless presentation of cumulative evidence." FED. R. EviD. 403; see also MCCORM1CK, supra note 18, § 185.

91. United States v. Zeiger, 350 F. Supp. 685, 688 (D.D.C. 1979); FED. R. Evid. 401.

92. See supro notes $73-76$ and accompanying text.

93. See FED. R. Evid. 403. 
Dalton's work suggests that expert testimony on PMS syndrome would be relevant in the context of a diminished capacity defense. Thus, under the McCormick approach the testimony should be admitted unless the prejudicial effect of such testimony outweighs its probative value or if another reason for exclusion ${ }^{94}$ is present. A court should consider, for example, Dr. Dalton's admonition to "remain suspicious of women who plead that premenstrual syndrome is a reason for mitigation or dimimished responsibility."9s A court should imsist that an expert seeking to testify about a particular defendant's disorder possess clear diagnostic proof that the defendant suffers from PMS syndroine. The court should accept nothing less than medical, prison, or other records indicating cyclically recurrent criminal, violent or other beliavior indicating mental impairment present only during the premenstrual periods over an extended period of time. Absent such evidence, expert testimony concerning a defendant's alleged suffering from PMS syndrome would be likely to confuse or mislead the jury. The probative value of such evidence would also be low. As a result, the balancing test concerning the admissibility of evidence would dictate the exclusion of such testimony.

\section{Conclusion}

As the debate concerning PMS syndrome has increased throughout the United States, it is expected that a female defendant will seek to use PMS syndrome as a defense to a criminal charge. This note lias sought to provide a framework within which a court miglit evaluate a proffer of expert testimony on PMS syndrome in a criminal trial. Primarily, the "general acceptance" standard as first articulated in Frye $v$. United States lias been relied on as a tool to assess the admissibility of such testimony. Existing scientific literature appears to reject the possibility that PMS syndrome could cause a type of temporary insanity. The literature, lowever, does not conclusively indicate whether PMS syndrome might impair mental function sufficiently to establislı a defense of diminisled capacity. Thus, whether use of the Frye test will admit or exclude expert testimony on PMS syndroine in the context of a diminisled capacity defense cannot be predicted. The less rigourous balancing approach, lowever, wonld appear to require a court to admit

94. See supra note 90.

95. Cyclical Criminal Acts, supra note 6, at 1071. 
expert testimony on PMS syndrome once it has been established that a defendant did $\mathrm{m}$ fact suffer from this disorder.

Marc P. Press 


\section{ANNOUNCEMENT}

We have purchased the entire back stock and reprint rights of -

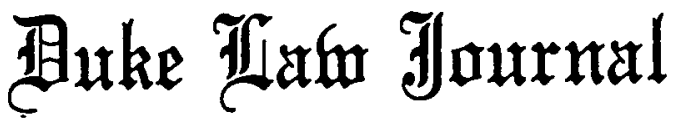

Complete sets to date are now available. We can also furnish simgle volumes and issues.

\section{WILLIAM S. HEIN \& CO., INC.}

1285 Main Street Buffalo, New York I4209 